\title{
PDVSA \\ AND THE NATIONALIZATION \\ OF THE OIL INDUSTRY \\ IN VENEZUELA
}

DOUGLAS DELGADO-LANDAETA*

Fecha de recepción: 14 de agosto de 2014.

Fecha de aceptación: 21 de abril de 2015.

I

INTRODUCTION: BRIEF HISTORY

OF THE VENEZUELAN ECONOMY

Before the arrival of the Oil Industry in Venezuela, Venezuela had an agrarian economy. Its main products of export were cocoa, coffee, livestock, among others. The majority of these products were exported to the European markets. Ever since the Venezuelan independence, the country was ruled by Warlords that embarked on a series of political philosophies that can be considered the earlier stages of the populism that followed in the XX century (Niño, 2012).

The existence of oil was already known to Venezuelan indigenous prior to the Spanish arrival in the country. However, it was not until 1878 that Manuel Pulido and other businessmen founded Compañía Nacional Minera Petrolia del Táchira under a concession from the central government in Caracas.

Even after the establishment of Compañía Nacional Minera Petrolia del Táchira, the country still remained an agrarian based economy. It was after 1908 when then dictator Juan Vicente Gomez granted concessions to foreign companies giving Venezuela newer technology necessary for crude exploration, production, and refining.

* Houston, TX, USA. +1.281.750.9491. 
II

\section{VENEZUELA: FROM A BANANA REPUBLIC TO AN OIL NATION}

After the «discovery» of oil in Venezuela, the government started granting concessions to foreign oil companies. Traditionally, in Venezuela there has been the common myth that foreign oil companies were "exploiting» the resources that belong to the people. In addition, Venezuelan culture has never been open to the idea of free markets and private property. As a result of cultural beliefs and political desire to exercise more power and exploitation in the territory it controls, the state began to increase taxes and finally nationalization of those privately held oil companies.

Before I continue, It is important to analyze the myth of exploitation the foreign companies were blamed for. To begin with, the myth of exploitation can be easily refuted by pointing out that foreign companies were employing voluntary local labor and were using the resource, oil, to satisfy consumers demand in either Venezuela or elsewhere in the world. Furthermore, these so called exploitators brought to the country the technology that was not produced locally something not mentioned by many intellectuals and local writers. Another common demagogue commonly used in Venezuela, has been that the minerals, in this case oil, belongs to the nation or the people of Venezuela, but in reality is to the state (Nino, 2012). Murray N Rothbard pointed out, all of these problems would had been solved with the establishing property rights of the minerals of the land that is been explored. However, it is easier said than done. As explained above, initially the idea of free market would not fit well into the Venezuelan mentality because of these common cultural barriers. While there had been few attempts to open up the economy, these attempts were almost dead on arrival.

Conversely, after foreign companies began extracting oil, the country's output began to rise steadily and it was in 1970 when Venezuela reached its peak and produced 3,780,000.00 barrels of oil making Venezuela the world's top oil exporter (Niño, 2012).

During this period Venezuela became a victim of the so-called «Dutch Decease.» The arrival of such decease had to do, in great part, with the previous economic policies of previous govern- 
ments. Had Venezuelan governments engaged towards privatization of minerals, tax cuts, and other free-market reforms, the impact of oil dependency could had been avoided or greatly reduced. Unfortunately, due political demagogue and the traditional rent-seeking mentality among the local population the government did not engage in such policies (Hirschbold, 2000).

By mid 1970s, local political demagogue and an international movement towards nationalism lead to the nationalization of all foreign owned assets in Venezuela giving birth to Petroleos de Venezuela, S.A. (PDVSA) (Hernandez, Grisanti, 1974).

III

PDVSA: MYTH OR REALITY?

There has been false illusion in Venezuela, created mostly by politicians as well as PDVSA's own PR team, that made employees and the rest of the nation believe that PDVSA, or the state's oil monopoly, was some sort of the goose of the golden eggs. Anyone who entered PDVSA's labor force believed he or she will have a «secured» retirement account, cannot be fired, and enjoy benefits above what any other private company could offer.

Such illusions could only be possible in the short to medium term. Monopolies as well as vertically integrated firms face the economic calculation problem. Huerta de Soto (2009) explains that «as the division of knowledge becomes broader, deeper and more detailed, and the economic progress becomes more complex, it becomes more difficult for a company to expand.» Along with the labor market rigidity, PDVSA employees lived in a government create bubble of job security and higher wages and benefits than most of those in the private sector.

Before the nationalization, the Venezuelan government saw its revenues double. This huge increase, along with political ambitions and demagogue, lead to the nationalization of all foreign assets (Hirschbold, 2000). There were 14 companies in total that were taken over by the government in 1976 and by 1986 PDVSA merged most of them and left only three out of those 14, Lagoven, Maraven, and Corpoven. 
As expected as soon as the nationalization becomes effective, the results were starting to be seen. The massive influx of money the government started to receive due to high oil prices, led to massive government spending in public buildings, roads, and like any other democratic government, government debt became also a problem. As expected, consumers began to spend part of this new influx of money leading to chronic price inflation. When the oil price plummeted, in the mid 1980s the government faced the same situation all governments face when the bubble is bursting. Basically, it saw its revenues plummet and its public spending was affected by the collapse of the oil price (Nino, 2012).

PDVSA as a vertically integrated company faced several problems that can be expected on such firms. For instance, the economic calculation in the different stages of production. A fully integrated firm is able to make internal calculation only because of the existence of a market price. If such market would not exist, then the firm will not be able to determine in which stage is making losses or profits (Huerta de Soto, 2009). Since PDVSA was and is monopoly in the country, it had no way of knowing which stage was being profitable or not at least in the local market. As a result, it was constantly challenged by the allocation of factors in the various stages.

In today's economy there have been several cases that prove the above statement. In the energy industry, there have been cases in which oil companies sell their refineries and midstream operations or simply divest their assets in such stages of productions. ConocoPhillips and Marathon Petroleum are two of the most recent examples in the oil industry. Since the free market always tends to establish the most efficient and profitable type of production (Rothbard, 1962), one can conclude that the PDVSA experiment was and has been a fraud.

For every capital good there must be a market in which one can buy and sell that good; this did not happen in Venezuela with PDVSA. As the area of incalculability increases, the degrees of irrationality, misallocation, loss, impoverishment, etc. become greater (Rothbard, 1962). Such problems were being face by the company ever since the nationalization in 1976. After the oil nationalization, the country as a whole has never reached its peak in total oil produc- 
tion, it has had a mediocre production in net oil export, and total refining capacity has been in an almost non-stop decline. The following charts give an illustration of the company's performance:

VENEZUELA TOTAL OIL PRODUCTION (1980-2013)

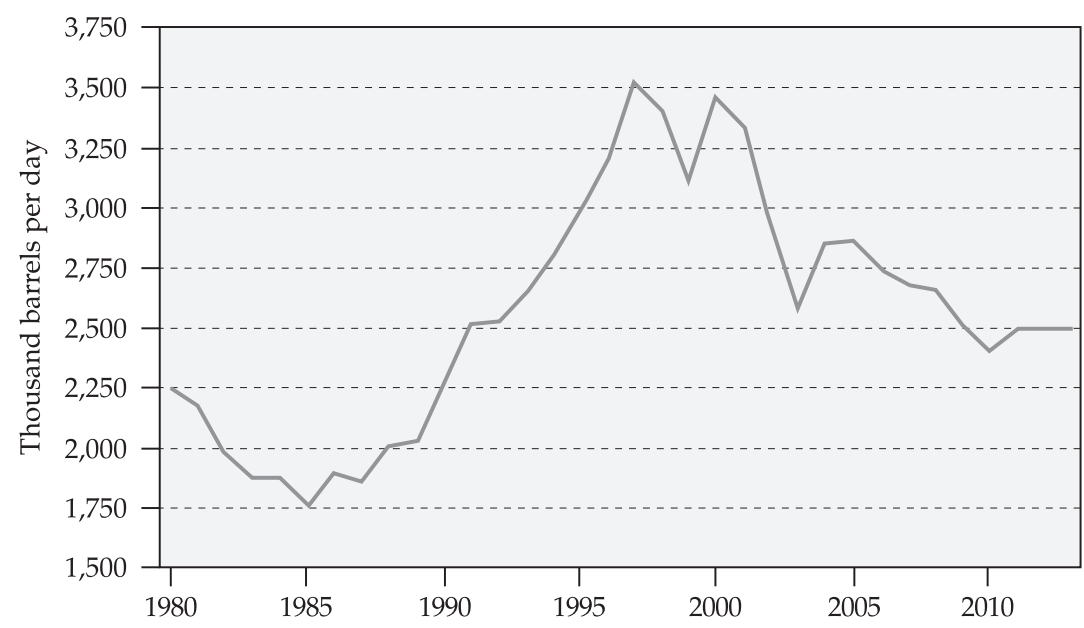

Source: U.S. Energy Information Administratrion.

VENEZUELA REFINERY CAPACITY (1980-2012)

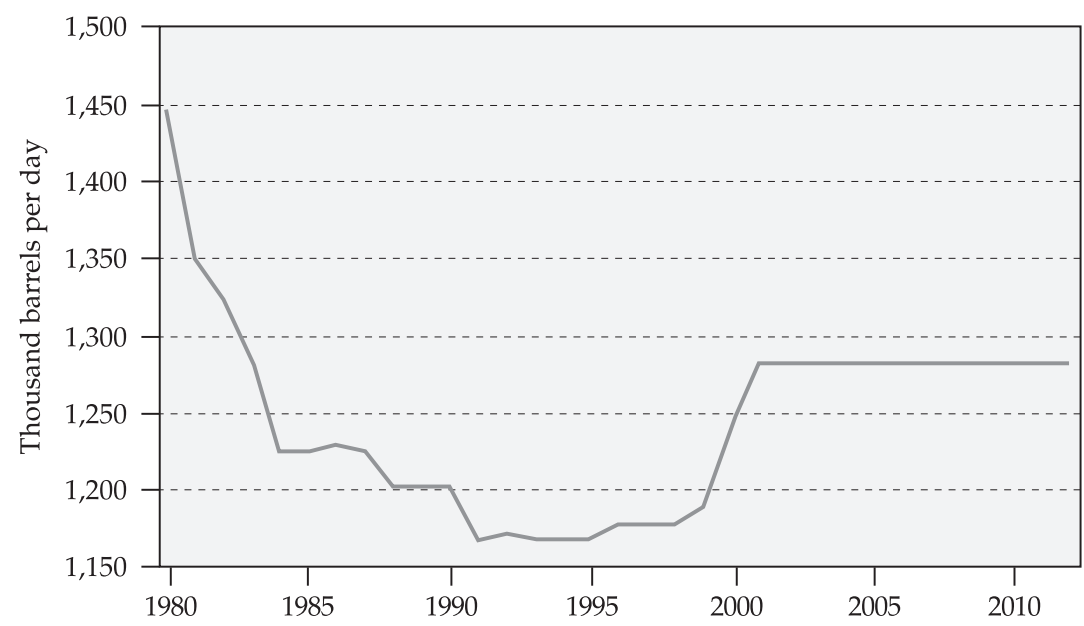

Source: U.S. Energy Information Administratrion. 
VENEZUELA ESTIMATED PETROLEUM NET EXPORTS

(1980-2012)

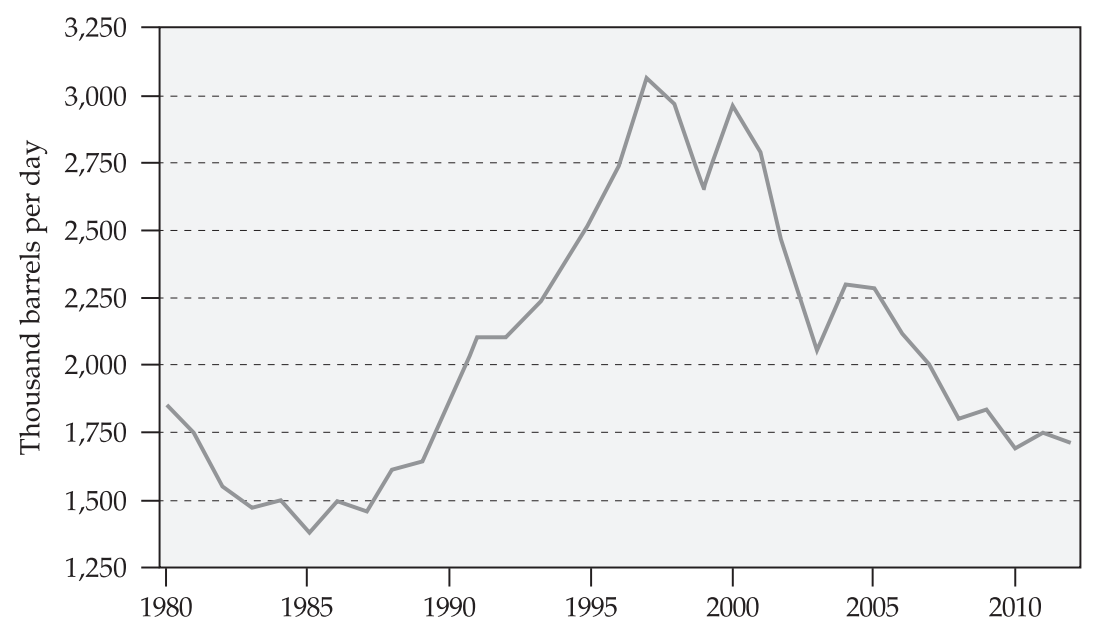

Note: The «estimated petroleum net exports» are calculated by subtracting «oil consumption» from «total oil production».

Source: U.S. Energy Information Administratrion.

As the charts above show, PDVSA's performance for most of the years after the nationalization has been all but exemplar. However, this is not the concept that has been sold to its employees and the Venezuelan public in general.

Furthermore, evidence of PDVSA's poor performance in the country can be easily seen by the fact that by the late 1980s early 1990s the country had to open borders to foreign capital mainly due to excesive government taxation and low revenues (Marsh, 2008, pp. 461). The fact that PDVSA was not able to stay competitive in its local market is enough evidence of the problem that many monopolies face.

IV

VENEZUELA: A NATION WITH

A RENT SEEKING MENTALITY

Venezuela, a renter nation, that has, for the most part, lived of the income perceived from its natural resources, created the 
perception to its citizen that the country can live off from its national resources (Niño, 2012). The income the state perceived from the oil export was used mainly for building public infrastructure, welfare support, and for political enrichment.

While there has been some sort of blame on the abundance of natural resources for the country's lack of economic performance and continuous underdevelopment, Venezuela's continuous economic backwardness relies more on the mentality of its people and the never ending political demagogue.

In Venezuela, there has never been an industrial revolution per se. With the birth of the petro state, the state's power grew to its current size. As the state's power grew, politicians put themselves in charge of the country's planning, and as we may expect, they have been greatly inefficient.

In Venezuela, as well as most of Latin America, there has never been a system that encourages competition in the private sector (Hirschbold, 2000). Hirschbold (2000), points out that Venezuelan private companies were being protected by the state from 1950s, 1960s, and 1970s through tariffs and other barriers erected by the government. He also further points out that the private sector was constantly subsidized by the government. These protective measures also «benefited» PDVSA. By being protected by the state, PDVSA was been able to enjoy relatively success in the country for the years after the nationalization.

Moreover, Hirschbold (2000) pointed out state employment in Venezuela more than tripled after the nationalization of the oil companies from 1975 to 1997 . The massive increase in government employees and bureaucrats creates a bigger burden on the state's finances and a deeper rent-seeking mentality among Venezuelans.

A common problem that this nationalization brought to Venezuela was the so called «Dutch Disease.» After the arrival of oil companies into Venezuela and the state's growth going deeper into the economy, the country's main revenue has been coming from its oil sales. The myth created among the population was that Venezuela's vital source must come from oil (Hirschbold, 2000). Such theory is not only dangerous, but also its application is counterproductive for the whole economy. Venezuela's 
immense dependency from its resources, namely oil, and its continuous protectionist measures has kept the country in a constant underdevelopment. This lack of development has also had its effect on PDVSA. By being a monopoly, PDVSA has not been able to compete efficiently with other major corporations such as ExxonMobil, Chevron, BP, among others. The government's interference in the company's policies as well as PDVSA inherently inefficiency to operate as a private company has taken PDVSA to a low performance among other privately owned oil companies. Manzano (2008, pp. 8) shows that PDVSA's decline in revenue was linked to a collapse in oil price. Although the decline in oil prices may have had some effect in the collapse of profit margins, the collapse in profit margins can also be attributed to a poor effort in reduce operating costs.

Furthermore, before the arrival of Hugo Chavez to the presidency, PDVSA's employees, as well as the rest of the country, enjoyed a rigid labor market that allowed them to believe that their jobs were safe forever. Even today the labor market is still a very rigid one as pointed out by The Heritage Foundation (See Apendix). As a result of these policies, employers were always reluctant to hire new employees. Therefore, in 1998 47.5\% of the labor market was working on the underground economy. Hirschbold (2000) points out that during the oil bonanza the country received in the early years of the oil industry, the government further developed the concept of a welfare state among the local inhabitants. One of the major consequences of such policies was the never ending lack of work ethics among the labor force. While some companies were successful in finding efficient managers, there were many others which have to always deal with the problem.

\section{$\mathrm{V}$ \\ COULD PDVSA SURVIVE IN A COMPETITIVE AND FLEXIBLE LOCAL ECONOMY?}

Hirschbold (2009) correctly pointed out that Venezuela's restrictive labor markets as well as its protectionist measures had contributed to the country's constant underdevelopment. 
Traditionally, when a country embraces a competitive policy, with no barriers to enter the market, its standards of livings will rise. A country with limited resources will be immensely poorer should it engage in opposite policies. This will also apply to a country with vast resources available as it was the case of the former USSR. Should Lichtenstein engage in protectionist policies, it could probably survive but with a much smaller standards of living, and probably its local population will have to return to hunting or farming for surviving.

The case for PDVSA, and Venezuelan private sector to an extent, is similar to the case I explained above. PDVSA, which simply is the result of the government aggression towards foreign private companies and capital, had enjoyed a monopoly position for most of the years after the nationalization. Interestingly enough, the company had never reached the previous production record that was set by all the private companies that were operating in the country before the first nationalization of 1975.

Murray N Rothbard (1962) pointed out, as did Mises in 1920, the economic calculation on Monopoly companies will be impossible and it would eventually lead to its own collapse. In the case of PDVSA, the problem is even worse since the company not only enjoys a monopoly in the country, but also labor markets are too rigid. In the event that top management needs to cut production and lay employees off, so it can position better in the event of a market downturn, it would be a very tiresome task. This is not the case for other private oil companies in the United States, which in the oil crash of 2008, many private companies laid off a big percentage of their task force. Such reduction is essential in times of crisis. Had labor markets, especially in Texas, been rigid, it could had been much worse.

One interesting fact that it is rarely mentioned or studied among Venezuelan economists and other so-called experts, it is that most of the technology that PDVSA uses comes from foreign private companies. PDVSA, which is simply the result of expropriation of foreign capital instead of domestic capital that was previously saved and invested, would had not reached its peak had it not been for previously invested foreign equipment and technology. In fact PDVSA's inefficiency can be seen when in the second 
phase of privatization, in which after the new concessions it saw its production increase by $50 \%$ but its operating cost by $175 \%$ (PDVSA, 2014). While the company's new management blames it on foreign companies and outsourcing technology, it never went on to described the company's benefits to its employees which were higher than those privately owned companies in the U.S.

Hirschbold (2009) describes that traditionally, Venezuela has never had a culture in which individualism and competitiveness is rewarded. He also points out that the policy of import substitution had a wrong impact on the country's economy. The policy's effect was that it created local wages more expensive in comparison with other Latin American countries, it also led imported food to be more expensive than domestic food, and it led many small farmers to purchase sophisticated capital equipment for their farms with which they had no knowledge of how to operate them and they later sold them out to bigger land owners that had the personnel capacity operating such machinery. Under such cultural «barriers» it would have been difficult if not impossible for PDVSA to survive.

It can be summarized that PDVSA as well as any other state owned vertically integrated oil firms would have never been able to compete with other privately owned companies. Not only did protectionist barriers allowed PDVSA to give its employees generous benefits, but also it allowed the state to fund its never ending social programs.

\section{VI}

\section{HOW COULD PDVSA SURVIVE IN A FREE MARKET} ECONOMY? OR COULD IT?

In a pure free market economy, entrepreneurs will always compete among each other in satisfying consumer demands. Their tasks also include forecasting future consumer demands and adjusting their companies to current market conditions, this will include laying off employees when necessary, cutting benefits when needed, expanding or halting current production, and making necessary investments in R\&D. In the case of the oil industry, the 
owner of the oil field will be able to cut production when he feels most appropriate and expand when he feels it as well. When the scenario is not as above, then two different scenarios can occur which are state owned oil fields and state leased oil field. In the first scenario, the state can never operate as a privately owned company and suffer the same fate of vertically integrated firms, which are economic calculation as well as operating inefficiencies. In the second scenario, the case that can be described as «Oil Communism» or the tragedy of the commons. In this case, oil operators will come to the field and extract as much oil as they can since there will be other firms extracting oil as well and they would like to extract as much as possible before it runs out. This is the case happening in Canada, Venezuela before the nationalizations, and in other parts of the world in which the government leases out the oil field. There are many reasons which would be argued as to why PDVSA must remain «working» for the people or state owned, but none of those reasons will deal with the root cause that has plagued PDVSA since its inception which is being an efficient oil firm able to compete on a worldwide scale. PDVSA, which is simply the result of government aggression and expropriation of privately held firms, must be sold in pieces to different buyers whether domestically owned or international. While there would be many opponents of such measure including politicians on both sides and voters in general, it is the only possible solution for such inefficient behemoth. One reason against the privatization that is commonly brought up when discussing privatization of minerals in a country is that a firm could grow to such extent that it will become a monopoly. Whilst monopolies are the result of government interference in the unhampered market, such theory is totally absurd. Rothbard (1962) pointed out the free market will always put a limit on the size of the firm. Whenever a company is making big profits other competitors will soon enter the field and take away profit from existing competitors. Only those competitors that correctly predict future consumer demands and operate more efficiently will be able to stay on business.

Traditionally, private companies obtain fuding from one or more investors. They can cut expenses whenever they see it most 
appropriate and invest in any other department or cut production as well. Since PDVSA does not have any private investor, it can never work as such. All those efforts they tried in the past such as working «independently» from the government were in vain. Economic calculation was always an issue and had it not been from outside market prices it would had been impossible to survive for all these years. Only as privately held, the company's owner and management can more efficiently expand or cut production capacity according to current consumer demands.

\section{VII CONCLUSION}

It can be concluded that PDVSA would have not existed in Venezuela without an environment which promotes and defend private property and free trade. In fact, much of the technology and capital equipment that has been used in PDVSA are not built in the country.

In order for Venezuela to have one or more global players in the oil industry, the country would have to switch radically towards privatization of land, resources, and any other government owned company. It will also require for labor markets to be liberalized, cut government involvement in the economy as much as possible as well as a radical change in the mentality of Venezuelans. Such measures, while it may be considered too extreme even for many Venezuelans, it will allow a rapid reallocation of the resources and entrepreneurs will make better use of them than government bureaucrats and politicians.

While such idea may seem unattainable from today's current situation, it does not necessarily has to such difficult task as it has been shown that ideas can bring down governments and systems overnight. Since entrepreneurship is innate to every human been (Huerta de Soto, 2009), once privatization occurs, those entrepreneurs that are better at allocating resources and satisfying consumer demands will be able to establish new firms that can compete with major players in the global arena. 


\section{BIBLIOGRAPHICAL REFERENCES}

Heritage Foundation (2015): «Index of Economic Freedom» Available at: http://www.heritage.org/index/visualize? countries $=$ venezuela\&type $=10$

Hernandez-Grisanti, A. (1974): «La Nacionalizacion del Petroleo en Venezuela.» Nueva Sociedad, n. ${ }^{\circ}$ 14, pp. 34-39.

HirschbOld, A. (2000): Understanding Business and Management in Venezuela. Loughborough University, UK.

Huerta De Soto, J. (2009): Socialism, Economic Calculation, and Entrepreneurship. Northampton, MA, USA.

MANZANO, O. (2006): "Venezuela after a century of oil exploitation.» Chapter for the book Venezuela: Anatomy of a Collapse.

MARSH, B. (2008): «Preventing the Inevitable: The Benefits of Contractual Risk Engineering in Light of Venezuela's Recent Oil Field Nationalization.» Standford Journal of Law, Business \& Finance, vol. 13: 2.

NiÑO, M.A. (1998): «Apertura petrolera: poder de PDVSA vs. poder del Estado.» Available at: http://www.monografias. com/trabajos65/a pertura-petrolera-venezuela/a perturapetrolera-venezuela3.shtml\#xunescenar

HeRnÁNDEZ, N.: «Una Mirada a la Crisis de Hidrocarburos». Monografias.com. Venezuela. Available at: http://www. monografias.com/trabajos $82 /$ mirada-crisis-hidrocarburosvenezuela/mirada-crisis-hidrocarburos-venezuela2.shtml

PDVSA (2012): «PDVSA: Acerca de PDVSA/ Historia». Venezuela. RotHBARD, M. (1962): Man, Economy, and State with Power and Market. Auburn, AL, USA. 
